\title{
Experimental Assessment of a Phase Change Material for Wall Building Use
}

\author{
Frédéric Kuznik ${ }^{\mathrm{a}, *}$ Joseph Virgone ${ }^{\mathrm{b}}$ \\ ${ }^{a}$ Thermal Sciences Center of Lyon \\ CNRS, UMR 5008, INSA de Lyon, Université Lyon 1 \\ Bât. Sadi Carnot, 9 rue de la Physique - 69621 Villeurbanne Cedex, France \\ ${ }^{\mathrm{b}}$ Université de Lyon, Université Lyon 1 \\ DGCB laboratory, ENTPE rue Maurice Audin \\ 69518 Vaulx-en-Velin Cedex, France
}

\begin{abstract}
The thermal performances of a PCM copolymer composite wallboard has been experimentally investigated in a full scale test room. The test cell is totally controlled so that a typical day can be repeated (temperature and solar radiative flux). Effects of the PCM are investigated comparing the results obtained with and without composite wallboards for three cases: a summer day, a winter day and a mid-season day. The results show that: (1) for all the cases tested, the decrement factor varies between 0.73 and 0.78 which is quite interesting for use in buildings and particularly for renovation; (2) the air temperature in the room with PCM lowers up to $4.2^{\circ} \mathrm{C}$, the comfort enhancement is more important if the surface temperatures are also considered; (3) the PCM wallboards enhance the natural convection in the room and then there is no thermal stratification contrary to the room without composite; (4) the numerical experiments are fully described and can then be used to evaluate PCM numerical modeling.
\end{abstract}


Key words: phase change material, wallboard, energy storage, experimental investigation, temperature fluctuation.

\section{Introduction}

Nowadays, thermal energy storage systems are essential for reducing dependency on fossil fuels and then contributing to a more efficient environmentally benign energy use [1]. As demand in thermal comfort of buildings rise increasingly, the energy consumption is correspondingly increasing. For example, in France, the energy consumption of buildings has increased by $30 \%$ the last 30 years. Housing and tertiary buildings are responsible for the consumption of approximatively $46 \%$ of all energies and approximatively $19 \%$ of the total $\mathrm{CO}_{2}$ emissions [2].

Thermal energy storage can be accomplished either by using sensible heat storage or latent heat storage. Sensible heat storage has been used for centuries by builders to store/release passively thermal energy, but a much larger volume of material is required to store the same amount of energy in comparison to latent heat storage. The principle of the phase change material (PCM) use is simple. As the temperature increases, the material change phase from solid to liquid. The reaction being endothermic, the PCM absorbs heat. Similarly, when the temperature decreases, the material changes phase from liquid to solid. The reaction being exothermic, the PCM desorbs heat.

The main disadvantage of light weight buildings is their low thermal mass.

\footnotetext{
* Corresponding author. Tel.: +33-472-438-461; Fax: +33-472-438-522

Email address: frederic.kuznik@insa-lyon.fr (Frédéric Kuznik).
} 
Obviously, they tend to large temperature fluctuations due to external cooling, solar heat or heating loads. Using PCM material in such building walls can decrease the temperature fluctuations, particularly in case of solar radiations loads. It is then a potential method for reducing energy consumption in passively designed buildings. This tendency is confirmed by numerous papers available in the literature during the last 20 years. For a review, see in [3], [4] and $[5]$.

When selecting a PCM, the average room temperature should be close to the melting/freezing range of the material. Moreover, the day temperature and solar radiations fluctuations should allow the material phase change. Then many factors influence the choice of the PCM: weather, building structure and thermophysical properties [6],..That's why experiments must be carried out to effectively assess the use of PCM.

In this study, three cases are tested, depending on the simulated season day. The PCM wallboard allows to reduce the overheating due mainly to solar radiations during the summer time. Then, the first case tested is a summer day. During the winter, the PCM composite included in walls stores surplus of energy during the day and releases it during the night. This feature is then examined simulating a winter day. The mid-season is the longest period of a year; the third case tested is then a mid-season day.

The first part of this paper deals with a bibliographical review of the PCM used in building walls (part 2). The experimental set-up is presented in the part 3 of this article. The PCM composite, the experimental test cell and the experimental protocol are fully detailed. In the third part, the experimental results are analyzed in terms of comparative thermal performances for the 
cases with and without PCM wallboard. Finally, the part 5 concerns the main conclusions of this study.

\section{Bibliographical review}

The PCM incorporated in building walls are used to enhance the storage capacity of a light weight structure. Usually, the PCM is incorporated either in gypsum or in concrete. In [7], dodecanol is incorporated in pumice concrete block. Even if the results are interesting for energy storage, the latent heat of the composite is relatively low. That's why the most interesting possibility in building application is the impregnation of PCM into porous material such as plasterboard.

Fatty acids and organic phase change materials were used in [8], [9] and [10]. Various building materials were used to evaluate their absorption properties and the resulting composites. The gypsum can absorb up to $25 \%$ t of PCM. The results show that gypsum-PCM composite can be used to reduce overheating.

Gypsum wallboard has also been studied, numerically and experimentally in a full scale test room, in [11]. Their numerical results are in good agreement with experimental data. moreover, the PCM used shows a decrease in overheating and a decrease of energy consumption.

PCM can be microencapsulated for being included in building materials. However, thermal performances of the composite highly depend on the microencapsulation process [12]. In [13], micro-encapsulated PCM is integrated into gypsum wallboard. full-size tests show that such composite lowers the tem- 
perature by up to $4^{\circ} \mathrm{C}$ and significantly reduces the number of hours with temperature above $28^{\circ} \mathrm{C}$.

The main problem with gypsum is the quantity of PCM that can be incorporated: the maximum weight ratio is about $30 \% w t$. To overcome this problem, [14] filled a PVC panel with polyethylene glycol phase change material. The results show that the small test cell temperature amplitude decreases up to $20^{\circ} \mathrm{C}$.

On the whole, the use of PCM in classical building construction material is limited by the possibility to incorporate an important quantity of material (up to $30 \% w t$ in gypsum). The composite material tested in this paper constituted of $60 \%$ wt of microencapsulated paraffin within a copolymer. Moreover, the surface mass of the PCM composite is $4.5 \mathrm{~kg} / \mathrm{m}^{2}$ which is quite lower than the plaster board value i.e. $8.1 \mathrm{~kg} / \mathrm{m}^{2}$ for a $10 \mathrm{~mm}$ thickness. Then, it is an interesting candidate for enhancing thermal storage capacity of light weight buildings, especially for renovation.

\section{Description of the experimental set-up}

The aim of this article is to evaluate a composite PCM using a comparative study. Thus, two series of experiments are led, with and without PCM. The section 3.1 is dedicated to a physical presentation of the composite PCM wallboard. The section 3.2 deals with the description of the full-scale test room MINIBAT. Finally, in section 3.3 the experimental protocol is explained. 


\subsection{Phase change material tested}

The product tested, ENERGAIN ${ }^{\circledR}$ has been achieved by the Dupont de Nemours Society and is constituted of $60 \%$ of microencapsulated paraffin within a copolymer. The final form of the composite PCM (see figure 1) is a flexible sheet of $5 \mathrm{~mm}$ thickness which density is about $900 \mathrm{~kg} \cdot \mathrm{m}^{-3}$. The thickness of the PCM is the result of a commercial compromise and allows $77 \%$ of optimal efficiency obtained with $1 \mathrm{~cm}$ thickness [15].

The thermal conductivity has been measured using guarded hot-plate apparatus [16]. The thermal conductivity is $0.22 W \cdot m^{-1} \cdot K^{-1}$ in liquid phase and decreases to about $0.18 W \cdot m^{-1} \cdot K^{-1}$ in solid phase.

The composite PCM enthalpy has been measured using a differential scanning calorimeter as illustrated in figure 2; the heating and cooling rate being $0.05 \mathrm{Kmn}^{-1}$. The thermal analysis is presented for the range $\left[-20^{\circ} \mathrm{C} ; 35^{\circ} \mathrm{C}\right]$. Two curves are presented: the freezing curve (cooling from $35^{\circ} \mathrm{C}$ to $-20^{\circ} \mathrm{C}$ ) and the melting curve (heating from $-20^{\circ} \mathrm{C}$ to $35^{\circ} \mathrm{C}$ ).

From the DSC curves, melting and freezing temperatures are $13.6^{\circ} \mathrm{C}$ and $23.5^{\circ} \mathrm{C}$ respectively. The measured latent heats of melting and freezing are respectively $107.5 \mathrm{~J} / \mathrm{g}$ and $104.5 \mathrm{~J} / \mathrm{g}$; and $72.4 \mathrm{~J} / \mathrm{g}$ and $71 \mathrm{~J} / \mathrm{g}$ for the range $\left[5^{\circ} \mathrm{C} ; 30^{\circ} \mathrm{C}\right]$. The table 1 reports thermal energy storage data from literature concerning building materials. From this table, the composite PCM described in this article has an important potential of thermal energy storage in building walls. This particularity is due to the possibility to incorporate much more $\mathrm{PCM}$ in the polymeric material than in a traditional construction material, for example: 
* $26 w t \%$ of fatty acids PCM in gypsum - see [22],

$\star 35 w t \%$ of paraffin in gypsum - see [23],

$\star 5.6 w t \%$ of butyl sterate PCM in concrete block; $8.6 w t \%$ of paraffine in concrete block - see [24].

\subsection{The test cell MINIBAT}

The experimental full scale test room MINIBAT is located in the test hall of the Department of Civil Engineering and Urban Planning of the National Institute of Applied Sciences in Lyon (CETHIL-INSA de Lyon, France). The figure 3 represents a scheme of the experimental set-up. The test room is composed of two identical enclosures called test cell 1 and 2. In our experiments, only the cell 1 has been used and then is called test cell in the rest of the paper.

The test cell, of volume $3.10 \times 3.10 \times 2.50 \mathrm{~m}^{3}$, is bounded on five sides by air volumes regulated at a constant temperature (the thermal guard). The sixth face is a glazed facade which isolates the test cell from a climatic chamber. A solar simulator completes the experimental set-up and allows to generate short-wave radiations in the test cell.

\subsubsection{The thermal guard}

The air in the thermal guard is controlled by the means of an air treatment system. Air diffusers are installed in the upper part of the thermal guard air whereas the air is extracted in the lower part. The configuration of the air distribution allows an acceptable air mixing inside the thermal guard. The air 
temperature inside the zone is entirely controlled with an accuracy of $\pm 0.5^{\circ} \mathrm{C}$. The temperature of the thermal guard is set to $20.5^{\circ} \mathrm{C}$ in our experiments to simulate adjacent rooms.

\subsubsection{The climatic chamber}

The climatic chamber temperature can vary between $-10^{\circ} \mathrm{C}$ and $40^{\circ} \mathrm{C}$ and can be dynamically controlled so that any temperature evolution can be generated. Fans are also used to obtain a homogeneous temperature in the chamber.

\subsubsection{The solar simulator}

In order to have a light source which reproduces best the solar effects, $1000 \mathrm{~W}$ CSI lamp is selected (gas-discharge lamps with metal halide). The figure 4 presents the comparison between CSI lamp and solar spectrum [25].

12 spotlights are placed on 3 horizontal lines (see figure 5), each line being tilted of an angle $\alpha$ : for line A $\alpha=0^{\circ}$, for the line $\mathrm{B} \alpha=25^{\circ}$ and for the line $\mathrm{C} \alpha=50^{\circ}$.

The radiative flux thus created penetrates in the cell via the glazed wall. The control makes it possible to dynamically control the level of radiative flux by the means of the number of lit spotlights.

\subsubsection{The test cell}

The compositions of the walls are described in the table 2 . The physical characteristics of the materials used are summarized in table 3. All the opaque walls are covered with the same coating: a gray diffuse paint which physical 
properties are a solar absorptivity $\alpha_{s}=0.67$ and a global emissivity $\varepsilon_{g}=0.95$.

\subsubsection{The measurement devices}

All the faces temperatures (internal and external) are measured using thermocouples of resolution $\pm 0.4^{\circ} \mathrm{C}$, each face being equipped with 9 thermocouples.

The temperatures of the climatic chamber and the different parts of the thermal guard are measured using Pt100 probes with an accuracy of $\pm 0.3^{\circ} \mathrm{C}$. The air temperature of the test cell is measured using radiation shielded Pt100 probes: the first one is positioned in the middle of the room at a height of $85 \mathrm{~cm}$; the second one is at a height of $170 \mathrm{~cm}$. The time evolution of the vertical radiative flux density on the glazed facade is measured using a pyranometer.

The acquisition of the various parameters is done by the means of a multiplexermultimeter connected to a PC. The control of the whole of the apparatuses, except climatic control, is made using software LABVIEW. The time step chosen between two series of measurement is $10 \mathrm{mn}$ and the duration of each test is three days. The results presented in the paper concern the two last days, the first being used to erase initial conditions effects.

\subsection{Experimental protocol}

Three of the test cell walls are modified to include, or not, the composite PCM described in part 3.1. The locations of these walls are shown in figure 5: these are north, east and west walls. The configurations of the walls with and without PCM are described in figure 6 . 
The U-value is used to characterize the wall transmittance and is defined as:

$$
\frac{1}{U}=\sum_{i} \frac{e_{i}}{\lambda_{i}}
$$

with $e_{i}$ the thickness of the layer $i$ and $\lambda_{i}$ its thermal conductivity.

Due to composite PCM properties, the U-value of the two walls tested are very close, with a value of about $U=0.59 \mathrm{~W} / \mathrm{m}^{2} \mathrm{~K}$. This feature is important to neglect the PCM composite insulation property in the problem.

The test presented in this article are of three types:

- a summer day case, for which the temperature of the climatic chamber varies between $15^{\circ} \mathrm{C}$ and $30^{\circ} \mathrm{C}$. In this case, there is a night cooling. For that purpose, a ventilation is switched-on between $[6 h-18 h]$ and $[30 h-42 h]$ (according to figure 7 it corresponds to the $T_{c l}<22.5^{\circ} \mathrm{C}$ - the time scale of the figures does not correspond to a day time scale), the airflow rate being $92 \mathrm{~m}^{3} / \mathrm{h}$ (ie. 3.8ACH) and the air coming from the climatic chamber. Such night ventilation is suitable to improve the PCM storage/release effects [26].

- a mid-season day case, for which the temperature of the climatic chamber varies between $10^{\circ} \mathrm{C}$ and $18^{\circ} \mathrm{C}$.

- a winter day case, for which the temperature of the climatic chamber varies between $5^{\circ} \mathrm{C}$ and $15^{\circ} \mathrm{C}$. A $1500 \mathrm{~W}$ heating system has been placed into the room with a regulation at $20^{\circ} \mathrm{C}$ (the heating system works when the temperature in the room is below $20^{\circ} \mathrm{C}$ ).

For all the cases tested, the solar radiative fluxes are the same. The climatic chamber temperature $T_{c l}$ and the radiative fluxes $(E)$ are presented figure 7 . Obviously, these conditions are the same for the cases with and without PCM materials. We can notice the good repeatability, for the chosen period of $24 h$, 
of the controls of the climatic chamber temperature and lighting of the projectors.

In conclusion, the experimental methodology allows us to obtain a complete boundary conditions description and the temperatures inside the test cell, the following values being dynamically measured:

$\checkmark$ the interior and exterior wall surface temperatures,

$\checkmark$ the room air temperature in the middle of the room and at two different heights,

$\checkmark$ the climatic chamber temperature,

$\checkmark$ the radiative flux density in front of the glazed façade on the climatic chamber side.

\section{Analysis of comparative thermal performances}

This section is devoted to an analysis of the thermal performances of the PCM wallboard. This analysis is held by comparing the results for the cases with and without PCM composite in the walls. The data compared are the room air temperature (figures 8, 10 and 12) and the modified wall surface temperature (figures 9, 11 and 13). The sections 4.1, 4.2 and 4.3 deals with the comparisons for the three cases considered in this study; the section 4.4 summarizes the results. 


\subsection{Experimental results for the summer case with night ventilation}

Figure 8 shows the room air temperature profiles for the PCM and regular wallboards. With regular wallboards, the air temperature is varying between a minimum of $18.9^{\circ} \mathrm{C}$ and a maximum of $35.3^{\circ} \mathrm{C}$ and $36.6^{\circ} \mathrm{C}$ for the probes at respectively heights $85 \mathrm{~cm}$ and $170 \mathrm{~cm}$. The difference between the two maximum temperature for the two probes at different heights is due to the thermal stratification of the room air. With PCM wallboards, the air temperature is varying between a minimum of $19.8^{\circ} \mathrm{C}$ and a maximum of $32.7^{\circ} \mathrm{C}$. Then, the $\mathrm{PCM}$ included in the walls allows to reduce the temperature fluctuations in the room: the maximum air temperature value decreases of about $3.9^{\circ} \mathrm{C}$ while the minimum air temperature increases of about $0.8^{\circ} \mathrm{C}$.

In this paper, the PCM effect on indoor air temperature is investigated using the decrement factor $f$. The decrement factor is the ratio between the amplitude of the indoor air temperature in the cell with PCM and the amplitude of the reference test cell air temperature (ie. with regular wallboards). For the summer case, the decrement factor is $f=0.79$.

An interesting observation concerns the differences between temperatures $T_{1}$ and $T_{2}$. A thermal stratification exists in the case of regular wallboards (a difference of $1.3^{\circ} \mathrm{C}$ for the temperature maximums between the two probes). This thermal stratification does not exist for the PCM wallboards. This must be due to higher natural convection effects. This effect improve the thermal comfort (by avoiding thermal stratification) and ,as we know, has never been observed before.

Figure 9 shows the evolutions of mean temperatures for the interior surfaces 
of the three modified walls, and for the cases with and without PCM material. The PCM walls temperature fluctuations are lower than for the ordinary walls; the evolutions of the east and west walls interior temperatures being similar. It is interesting to emphasize that the temperature evolution curves with and without PCM have a phase difference of about $40 \mathrm{mn}$. The last remark is valid for all the three cases tested: the PCM material "adds" inertia to the wall.

Concerning the east and west walls temperature curves, the PCM material causes a decrease of the temperature amplitude of about $3.5^{\circ} \mathrm{C}$. For the north wall, this decrease of the amplitude is about $2.8^{\circ} \mathrm{C}$. This value is lower than for east and west walls because the solar radiations are more important on the north wall.

\subsection{Experimental results for the mid-season case}

Figure 10 shows the room air temperature profiles for the PCM and regular wallboards. With regular wallboards, the air temperature is varying between a minimum of $17.4^{\circ} \mathrm{C}$ and a maximum of $30.8^{\circ} \mathrm{C}$ and $33.5^{\circ} \mathrm{C}$ for the probes at respectively heights $85 \mathrm{~cm}$ and $170 \mathrm{~cm}$. With PCM wallboards, the air temperature is varying between a minimum of $17.8^{\circ} \mathrm{C}$ and a maximum of $30.7^{\circ} \mathrm{C}$ and $29.0^{\circ} \mathrm{C}$ for the probes at respectively heights $85 \mathrm{~cm}$ and $170 \mathrm{~cm}$. Then, the $\mathrm{PCM}$ included in the walls allows to reduce the temperature fluctuations in the room: the maximum air temperature value decreases of about $2.3^{\circ} \mathrm{C}$ while the minimum air temperature increases of about $0.4^{\circ} \mathrm{C}$.

For the mid-season case, the decrement factor is $f=0.78$.

The figure 11 shows the evolutions of mean temperatures for the interior sur- 
faces of the three modified walls, and for the cases with and without PCM material. Concerning the east and west walls temperature curves, the PCM material causes a decrease of the amplitude of about $2.6^{\circ} \mathrm{C}$. For the north wall, this decrease is about $1.3^{\circ} \mathrm{C}$.

\subsection{Experimental results for the winter case}

Figure 12 shows the room air temperature profiles for the PCM and regular wallboards. With regular wallboards, the air temperature is varying between a minimum of $18.6^{\circ} \mathrm{C}$ and $18.1^{\circ} \mathrm{C}$ and a maximum of $30.4^{\circ} \mathrm{C}$ and $32.2^{\circ} \mathrm{C}$ for

the probes at respectively heights $85 \mathrm{~cm}$ and $170 \mathrm{~cm}$. With PCM wallboards, the air temperature is varying between a minimum of $18.6^{\circ} \mathrm{C}$ and $18.1^{\circ} \mathrm{C}$ and a maximum of $28.7^{\circ} \mathrm{C}$ and $28.4^{\circ} \mathrm{C}$ for the probes at respectively heights $85 \mathrm{~cm}$ and $170 \mathrm{~cm}$. Then, the PCM included in the walls allows to reduce only the maximum air temperature in the room of about $4.2^{\circ} \mathrm{C}$.

For the winter case, the decrement factor is $f=0.73$.

The figure 13 shows the evolutions of mean temperatures for the interior surfaces of the three modified walls, and for the cases with and without PCM material. Concerning the east and west walls temperature curves, the PCM material causes a decrease of the temperature amplitude of about $2.9^{\circ} \mathrm{C}$. For the north wall, this decrease is about $1.9^{\circ} \mathrm{C}$. 


\subsection{Discussion}

Three different external climates are tested to evaluate the potential of the PCM wallboards. For the three cases, the PCM wallboards allow to reduce the air temperature of the room, compared with regular wallboards. The decrement factor of the air temperature amplitude is varying between 0.73 and 0.78 . The lower decrement factor, which corresponds to the most efficient PCM use, concerns the winter case with the lower air temperature.

On the whole, the PCM tested enable to maintain the room air temperature within the comfort zone by decreasing the maximum air temperature of the room to a maximum value of $4.2^{\circ} \mathrm{C}$. This enhancement of the thermal comfort is more important if considering that the wall surface temperatures are also lower for the PCM wallboards than for the regular ones.

The last interesting observation concerns the thermal stratification of the room which exists for regular wallboards but not for the PCM wallboards. Of course, no thermal stratification means that natural convection exists in the room with PCM wallboards or is enhanced with PCM wallboards. Further investigations are needed to evaluate this effect, but it is not the purpose of our paper.

\section{Conclusions}

In order to investigate light building envelop, an experimental research has been carried out with wall containing PCM material. This is one of the rare study allowing a differential analysis of walls with and without PCM material, under controlled thermal and radiative effects. The tests concern the behavior 
of the test cell for summer, mid-season and winter cases.

Including the PCM wallboard reduces the air temperature fluctuations in the room. The decrement factor observed for the cases with PCM wallboard and with regular wall is about 0.7 for all the season tested. The wall surface temperatures fluctuations are also reduced.

For a building application, the PCM composite is interesting to enhance the human thermal comfort for three main reasons:

- The PCM material included in the walls strongly reduces the overheating effect (and the energy stored is released to the air room when the temperature is minimum).

- The wall surface temperature is lower when using PCM wallboard, then the thermal comfort is enhanced by radiative heat transfer.

- The natural convection mixing of the air is also enhanced by PCM material, avoiding uncomfortable thermal stratifications.

In order to validate the use of PCM wallboard for light weight building envelop, further investigations are needed. Numerical simulations must be carried out too, in order to investigate the total gain for real buildings. We think that the results described in this article can then be used as reference test-case for validations of numerical codes. We also need to look at modifications of the PCM wallboard position to enhance storage effects.

Finally, the experimental set-up is fully described sot that the data presented in this study can be used for the validation of PCM numerical modeling. 


\section{Acknowledgement}

The authors wish to thank Dupont de Nemours Society for their support and particularly the head of this project, Raymond Reisdorf.

\section{References}

[1] I. Dincer, M.A. Rosen, Thermal Energy Storage - Systems and Applications, Jhon Wiley and Sons, 2002.

[2] French Ministry of Ecology and Sustainable Developpment, Climate Plan 2004: let's act together to challenge of climate change, Report, 2004.

[3] V.V. Tyagi, D. Buddhi, PCM Thermal Storage in Buildings: A State of Art, Renewable and Sustainable Energy Reviews 11 (2007) 1146-1166.

[4] A.M. Khudhair, M.M. Farid, A review on energy conservation in building applications with thermal storage by latent heat using phase change materials, Energy Conversion and Management 45 (2004) 263-275.

[5] Y. Zhang, G. Zhou, K. Lin, Q. Zhang, H. Di, Application of latent heat thermal energy storage in buildings: State-of-the-art and outlook, Building and Environment 42 (2007) 2197-2209.

[6] K. Darkwa, P.W. O'Callaghan, D. Tetlow, Phase-change drywalls in a passivesolar building, Applied Energy 83 (2006) 425-435.

[7] D.W. Hawes, D. Feldman, D. Banu, Latent heat storage in building materials, Energy and Buildings 20 (1993) 77-86.

[8] D. Feldman, M.A. Khan, D. Banu, Energy storage composite with an organic phase change material, Solar Energy Materials and Solar Cells 18 (1989) 333-341. 
[9] D. Feldman, M. Shapiro, D. Banu, C.J. Fucks, Fatty acids and their mixtures as phase change materials for themal energy storage, Solar Energy Materials and Solar Cells 18 (1989) 201-216.

[10] D. Feldman, D. Banu, D. Hawes, E. Ghanbari, Obtaining an energy storing building material by direct incorporation of an organic phase change material in gypsum wallboard, Solar Energy Materials and Solar Cells 22 (1991) 231-242.

[11] A.K. Athienitis, C. Liu, D. Hawes, D. Banu, D. Feldman, Investigation of the thermal performance of a passive solar test-room with wall latent heat storage, Building and Environment 32 (1997) 405-410.

[12] M.N.A. Hawlader, M.S. Uddin, M.M. Khin, Microencapsulated PCM thermalenergy storage system, Applied Energy 74 (2003) 195-202.

[13] P. Schossig, H.M. Henning, S. Gschwander, T. Haussmann, Micro-encapsulated phase-change materials integrated into construction materials, Solar Energy Materials and Solar Cells 89 (2005) 297-306.

[14] M. Ahmad, A. Bontemps, H. Sallé, D. quenard,Thermal testing and numerical investigation of a prototype cell using light wallboard coupling vacuum isolation panels and phase change material, Energy and Buildings 38 (2006) 673-681.

[15] F. Kuznik, J. Virgone, J. Noel, Optimization of a phase change material wallboard for building use, Applied Thermal Engineering 28 (2008) 1291-1298.

[16] ASTM, Standard Test Method for Steady-State Heat Flux Measurements and Thermal Transmission Properties by Means of the Guarded-Hot-Plate Apparatus, Norm C177, 2004.

[17] D. Feldman, D. Banu, D.W. Hawes, Development and application of organic phase change mixtures in thermal storage gypsum wallboard, Solar Energy Materials and Solar Cells 36 (1995) 147-157. 
[18] L. Shilei, Z. Neng, F. Guohui, Eutectic mixtures of capric acid and lauric acid applied in building wallboards for heat energy storage, Energy and Buildings 38 (2006) 708-711.

[19] A. Sari, A. Karaipekli, Preparation, thermal properties and thermal reliability of capric acid/expanded perlite composite for thermal energy storage, Materials Chemistry and Physics 109 (2008) 459-464.

[20] L. Shilei, F. Guohui, Z. Neng, D. Li, Experimental study and evaluation of latent heat storage in phase change materials wallboards, Energy and Buildings 39 (2007) 1088-1091.

[21] D. Feldman, D. Banu, DSC analysis for the evaluation of an energy storing wallboard, Thermochimica Acta 272 (1996) 243-251.

[22] Shilei, L., Neng, Z., Guohui, F., Impact of phase change wall room on indoor thermal environment in winter, Energy and Buildings 38 (2006) 18-24.

[23] S. Scalat, D. Banu, D.W. Hawes, J. Paris, F. Haghighata, D. Feldman, Full scale thermal testing of latent heat storage in wallboard, Solar Energy Materials and Solar Cells 44 (1996) 49-61.

[24] T. Lee, D.W. Hawes, D. Banu, D. Feldman, Control aspects of latent heat storage and recovery in concrete, Solar Energy Materials and Solar Cells 62 (2000) 217-237.

[25] F. Allard, J. Brau, C. Inard, J.M. Pallier, Thermal Experiments of Full-scale Dwelling Cells in Artificial Climatic Conditions, Energy and Buildings 10 (1987) 49-58.

[26] G. Zhou, Y. Yang, X. Wang, S. Zhou, Numerical analysis of effect os shapestabilized phase change material plates in a building combined with night ventilation, Applied Energy 86 (2009) 52-59. 


\section{List of Tables}

1 Thermophysical properties of some composite PCM from literature.

2 Compositions of the walls - materials are given from interior to exterior.

3 Physical characteristics of the test cell materials. 


\begin{tabular}{lcccc} 
Composite PCM & $\begin{array}{c}\text { melting point } \\
{\left[{ }^{\circ} \mathrm{C}\right]}\end{array}$ & $\begin{array}{c}\text { freezing point } \\
{\left[{ }^{\circ} \mathrm{C}\right]}\end{array}$ & $\begin{array}{c}\text { latent heat } \\
{[\mathrm{J} / \mathrm{g}]}\end{array}$ & reference \\
\hline methyl palmitate-sterate/gypsum & 22.6 & 23.8 & 41 & {$[17]$} \\
dodecanol/gypsum & 20 & 21 & 47 & {$[7]$} \\
dodecanol/pumice concrete block & 12 & 14.9 & 12.7 & {$[7]$} \\
capric-lauric acids/gypsum & 19.1 & & 35.2 & {$[18]$} \\
capric acid/perlite & 31.8 & 31.6 & 98.1 & {$[19]$} \\
capric acid/perlite & 31.8 & 31.6 & 98.1 & {$[19]$} \\
capric-lauric acids/gypsum & 15.0 & 24.3 & 39 & {$[20]$} \\
emerest2326/gypsum & 16.9 & 19.3 & 35 & {$[21]$} \\
composite PCM & 13.6 & 23.5 & 106 & present study \\
\hline
\end{tabular}

Table 1

Thermophysical properties of some composite PCM from literature. 


\begin{tabular}{llc}
\hline wall & material & thickness $[\mathrm{mm}]$ \\
\hline floor & concrete & 200 \\
\hline vertical wall & plaster & 10 \\
& polystyrene & 50 \\
& plaster & 10 \\
& wood plate & 50 \\
\hline ceiling & plaster & 10 \\
& wood plate & 8 \\
& insulating material & 55 \\
& wood plate & 25 \\
\hline glazed facade & glass & 10 \\
\hline
\end{tabular}

Table 2

Compositions of the walls - materials are given from interior to exterior. 


\begin{tabular}{lccc}
\cline { 2 - 4 } & $\begin{array}{c}\text { density } \\
{\left[\mathrm{kg} / \mathrm{m}^{3}\right]}\end{array}$ & $\begin{array}{c}\text { heat capacity } \\
{[\mathrm{J} / \mathrm{kgK}]}\end{array}$ & $\begin{array}{c}\text { thermal conductivity } \\
{[\mathrm{W} / \mathrm{mK}]}\end{array}$ \\
\hline concrete & 400 & 919.5 & 0.16 \\
plaster & 817 & 1620 & 0.35 \\
wood plate & 544 & 1640 & 0.136 \\
polystyrene & 35 & 1210 & 0.04 \\
insulating material & 200 & 362.8 & 0.06 \\
glass & 2500 & 770 & 1.00
\end{tabular}

Table 3

Physical characteristics of the test cell materials. 


\section{List of Figures}

1 Dupont de Nemours material.

2 Differential scanning calorimeter melting and freezing curves for the composite PCM.

$3 \quad$ Scheme of the experimental set-up.

4 Comparison between CSI lamp and solar spectrum from [25].

5 Isometric diagram of the test cell with the 12 spotlights Locations of the modified walls.

6 composition of the walls with and without composite PCM.

$7 \quad$ Experimental climatic chamber temperature $T_{c l}$ and vertical radiative flux density $E$ on the glazed facade during the experiments.

8 Temperatures in the room for the summer case with ventilation - $T_{1}$ at height $0.85 \mathrm{~m}$ and $T_{2}$ at height $1.70 \mathrm{~m}$.

9 Experimental mean temperatures of the interior surfaces of east wall (a), west wall (b) and north wall (c) - summer case with ventilation.

10 Temperatures in the room for the mid-season case $-T_{1}$ at height $0.85 \mathrm{~m}$ and $T_{2}$ at height $1.70 \mathrm{~m}$.

11 Experimental mean temperatures of the interior surfaces of east wall (a), west wall (b) and north wall (c) - mid-season case.

12 Temperatures in the room for the winter case $-T_{1}$ at height $0.85 \mathrm{~m}$ and $T_{2}$ at height $1.70 \mathrm{~m}$.

13 Experimental mean temperatures of the interior surfaces of east wall (a), west wall (b) and north wall (c) - winter case. 


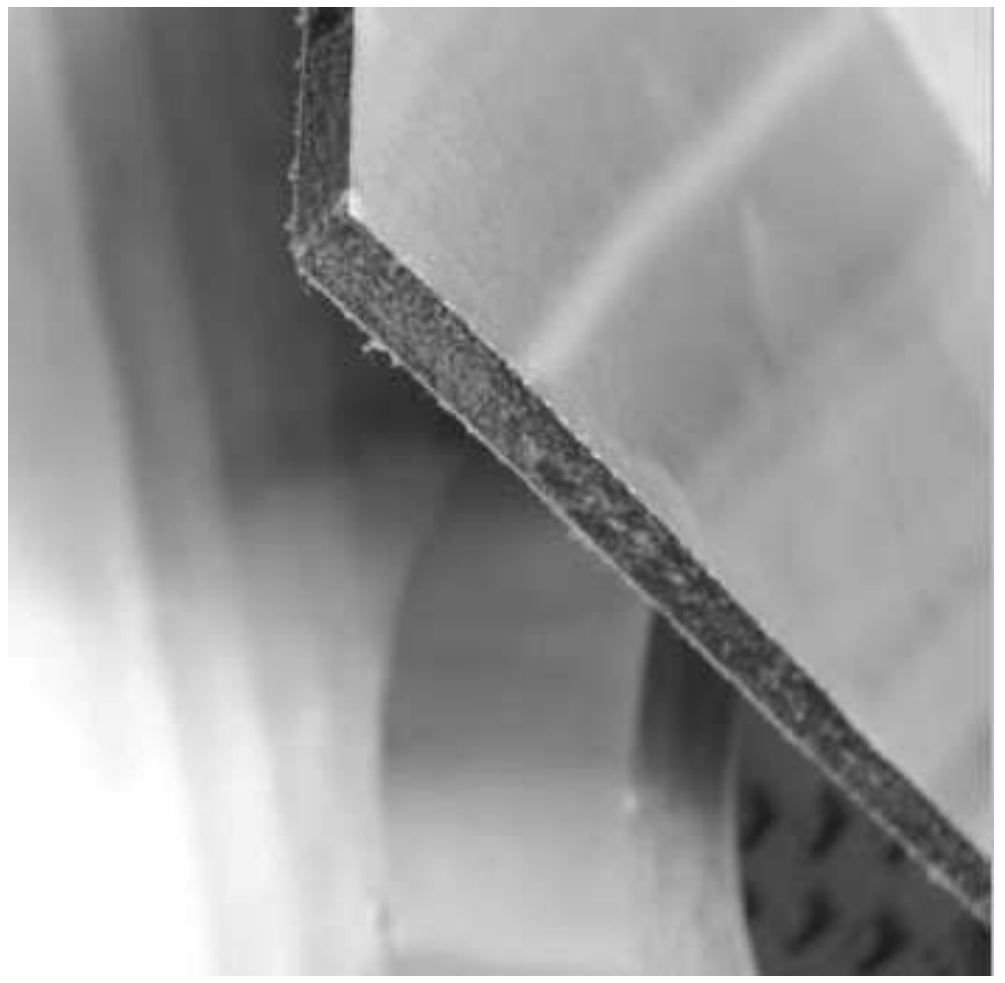

Fig. 1. Dupont de Nemours material. 


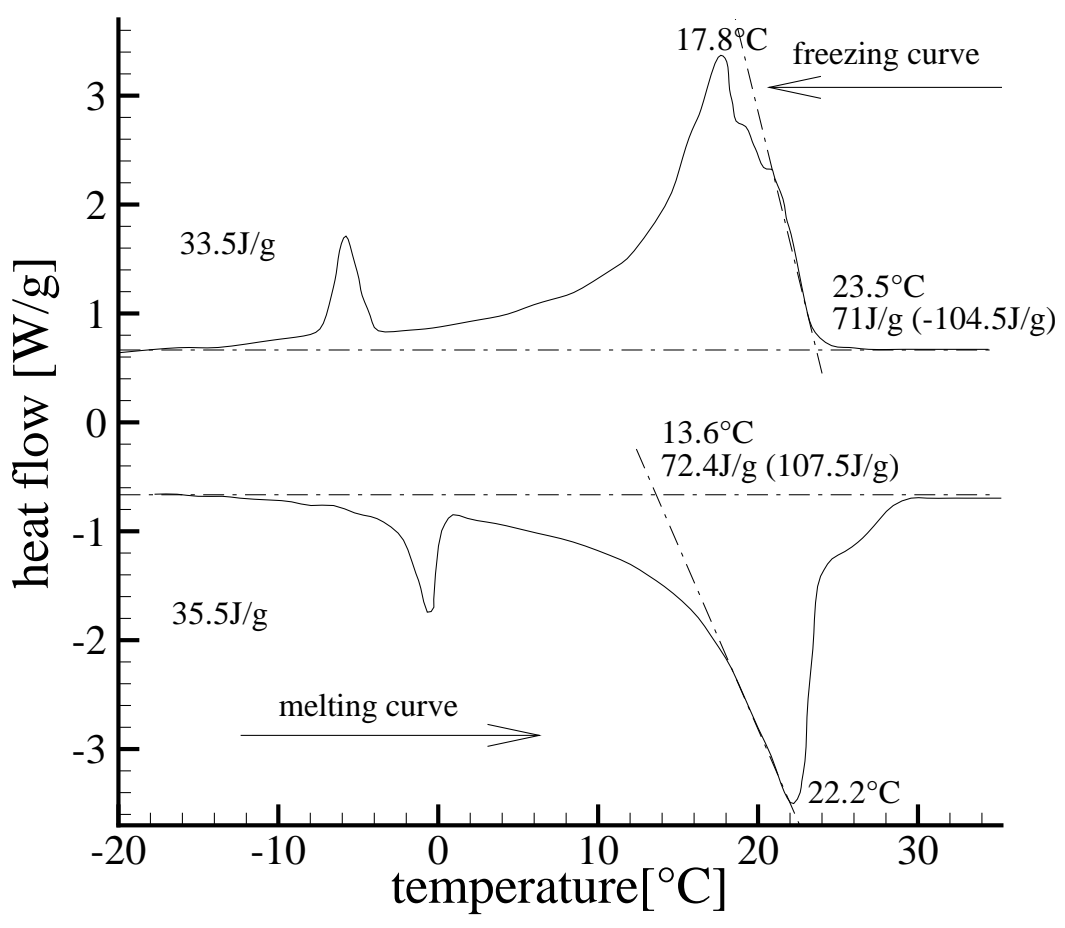

Fig. 2. Differential scanning calorimeter melting and freezing curves for the composite PCM. 

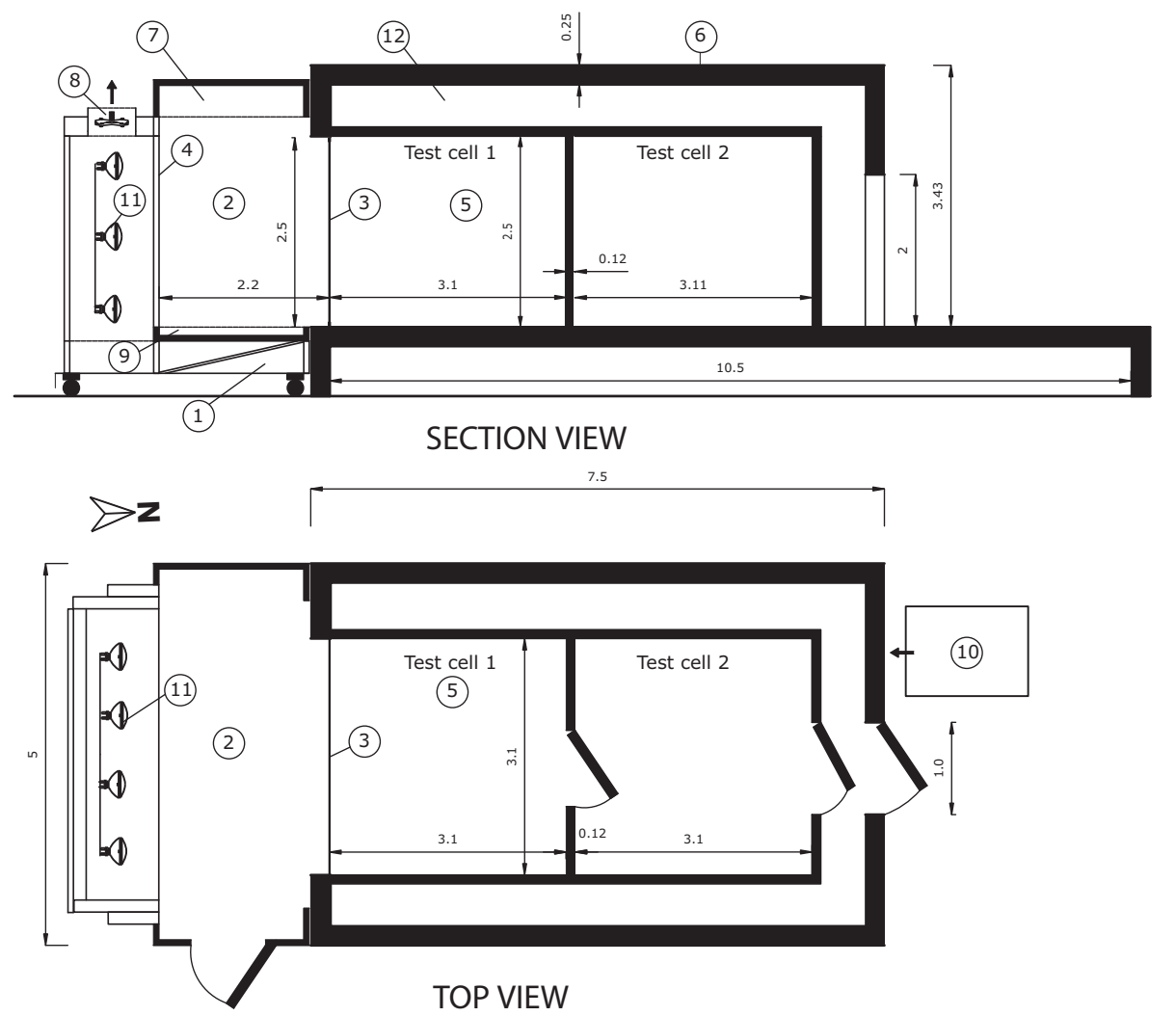

1 cooling unit; 2 climatic chamber; 3 simple glazing; 4 protection glass of the solar simulator; 5 test cell; 6 concrete; 7 air blowing plenum; 8 solar simulator's heat removal ventilators; 9 air extraction plenum; 10 HVAC unit of the thermal guard; 11 solar simulator; 12 thermal guard. (Metric units)

Fig. 3. Scheme of the experimental set-up. 


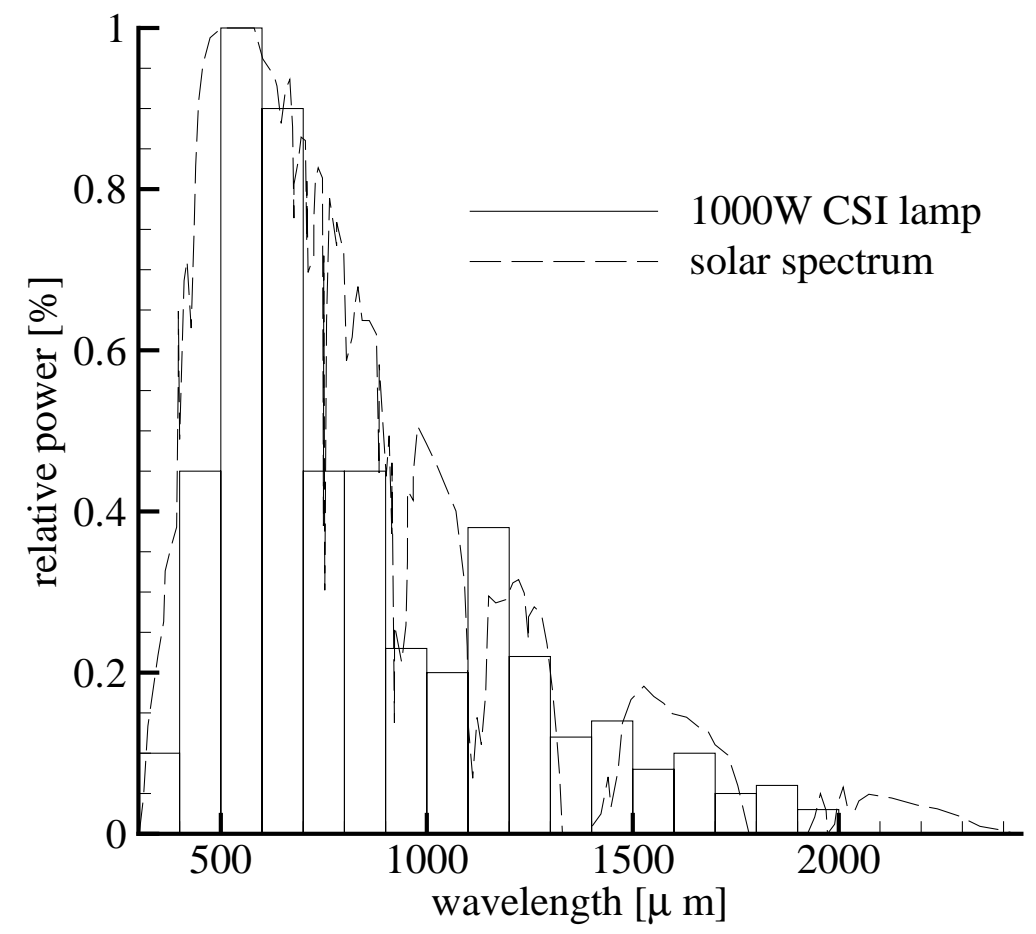

Fig. 4. Comparison between CSI lamp and solar spectrum from [25]. 


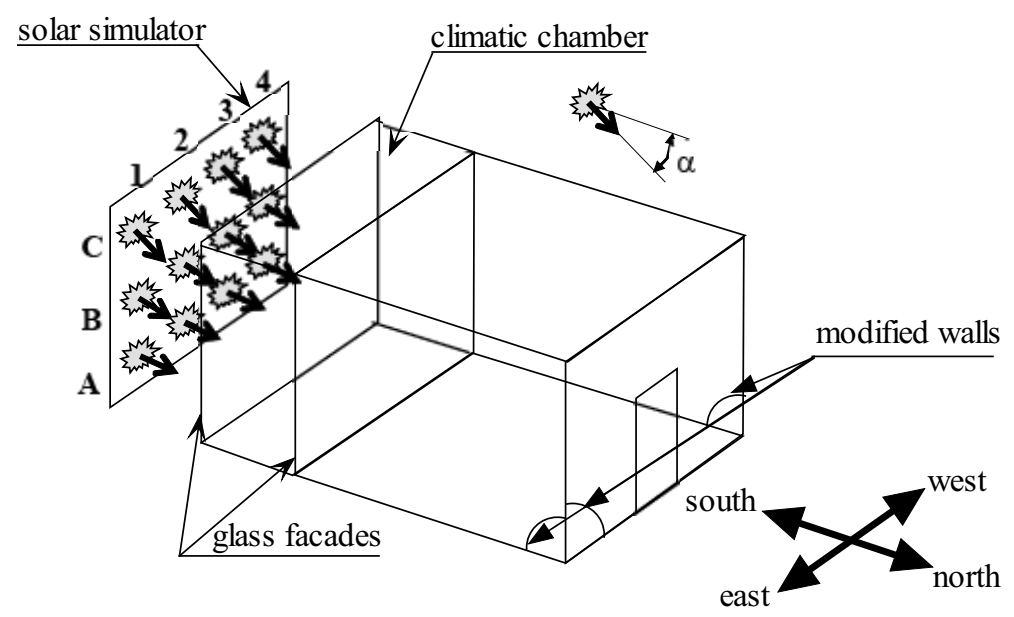

Fig. 5. Isometric diagram of the test cell with the 12 spotlights - Locations of the modified walls. 

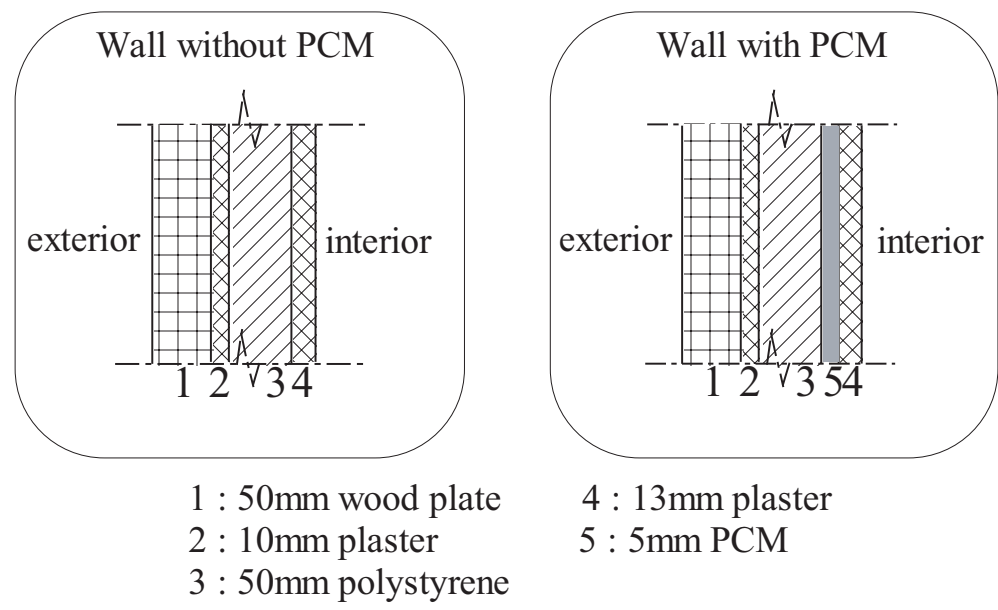

$4: 13 \mathrm{~mm}$ plaster

5 : $5 \mathrm{~mm}$ PCM

Fig. 6. composition of the walls with and without composite PCM. 

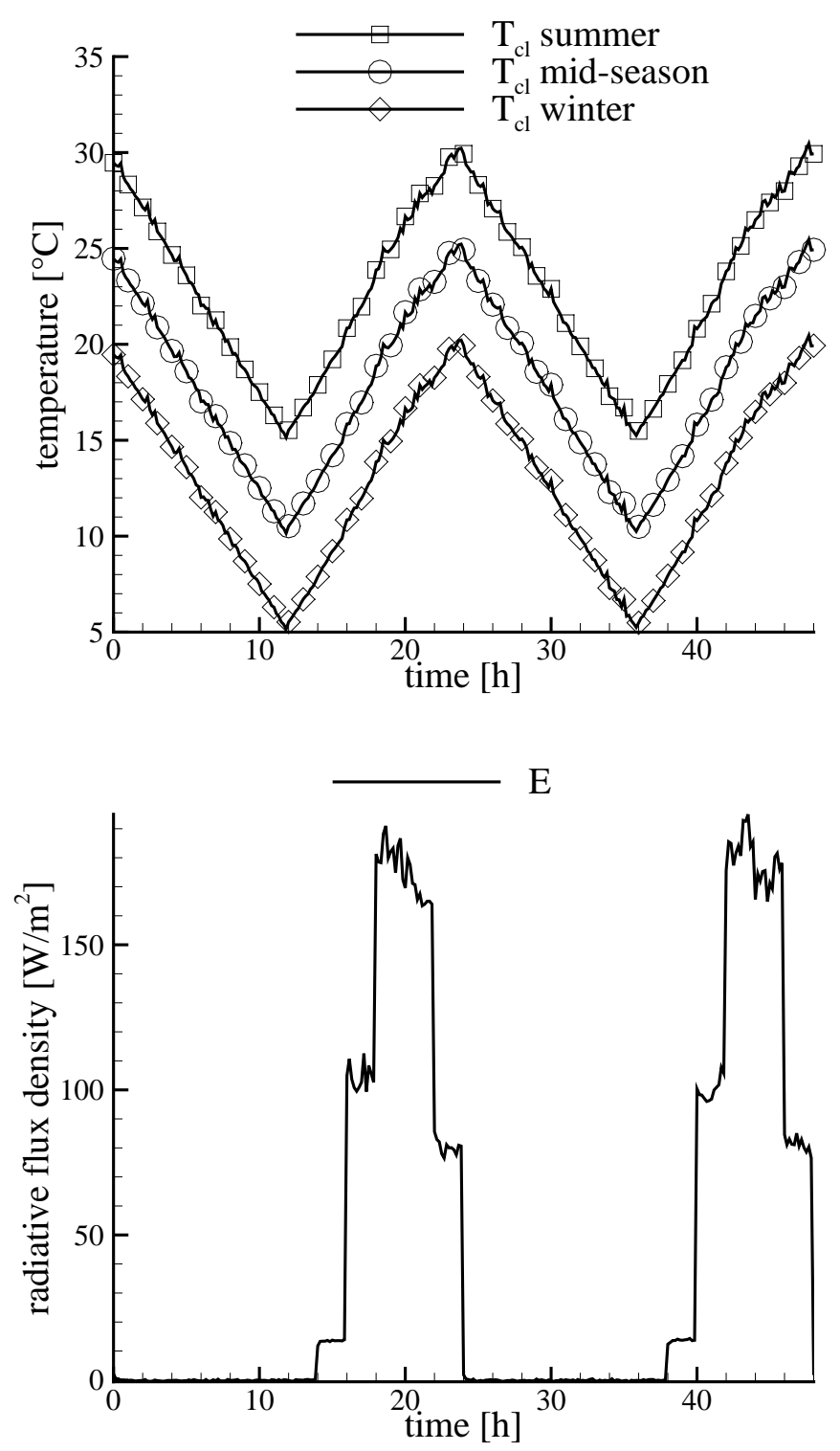

Fig. 7. Experimental climatic chamber temperature $T_{c l}$ and vertical radiative flux density $E$ on the glazed facade during the experiments. 


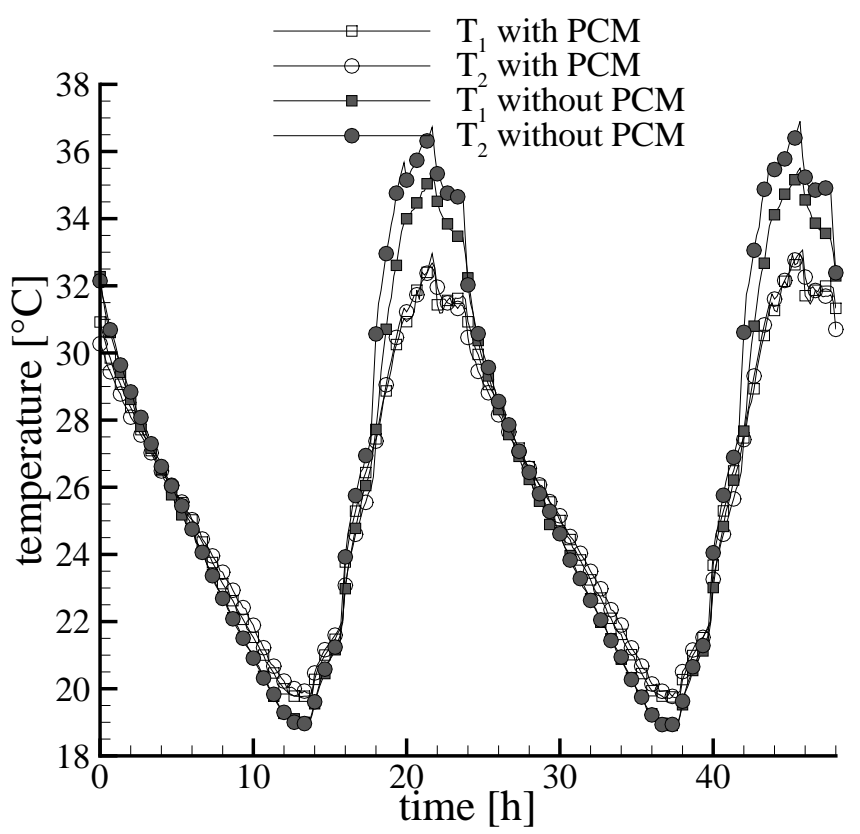

Fig. 8. Temperatures in the room for the summer case with ventilation - $T_{1}$ at height $0.85 \mathrm{~m}$ and $T_{2}$ at height $1.70 \mathrm{~m}$. 

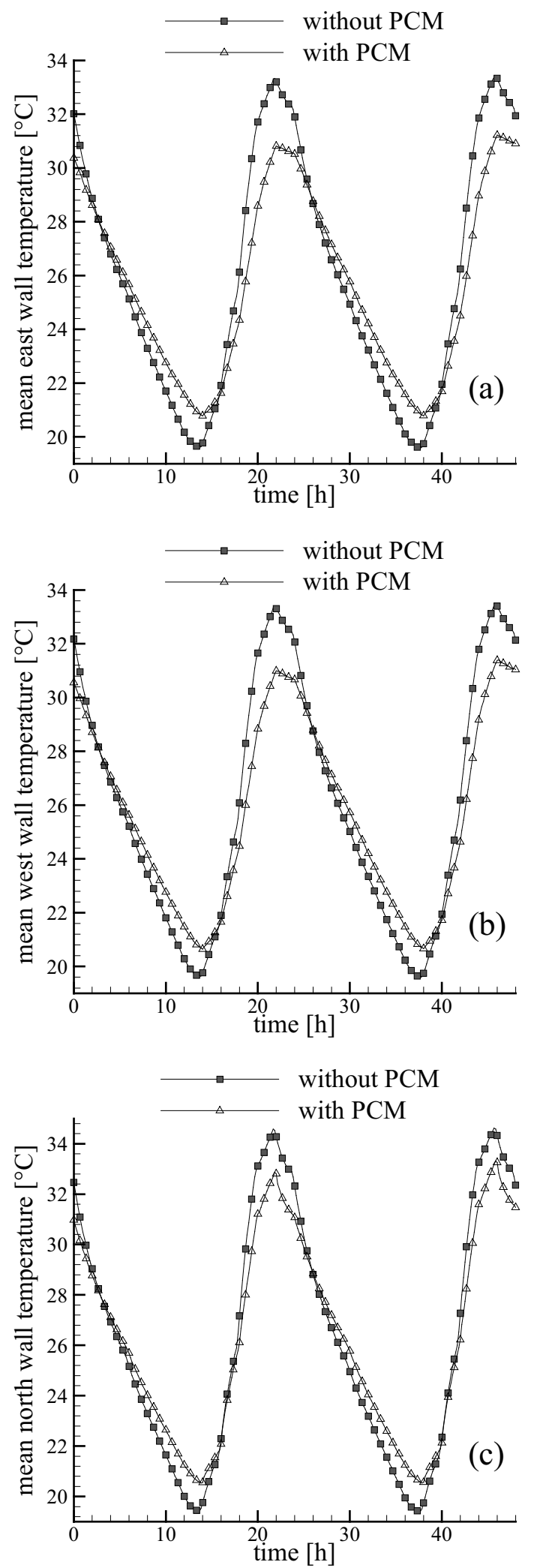

Fig. 9. Experimental mean temperatures of the interior surfaces of east wall (a), west wall (b) and north wall (c) - summer case with ventilation. 


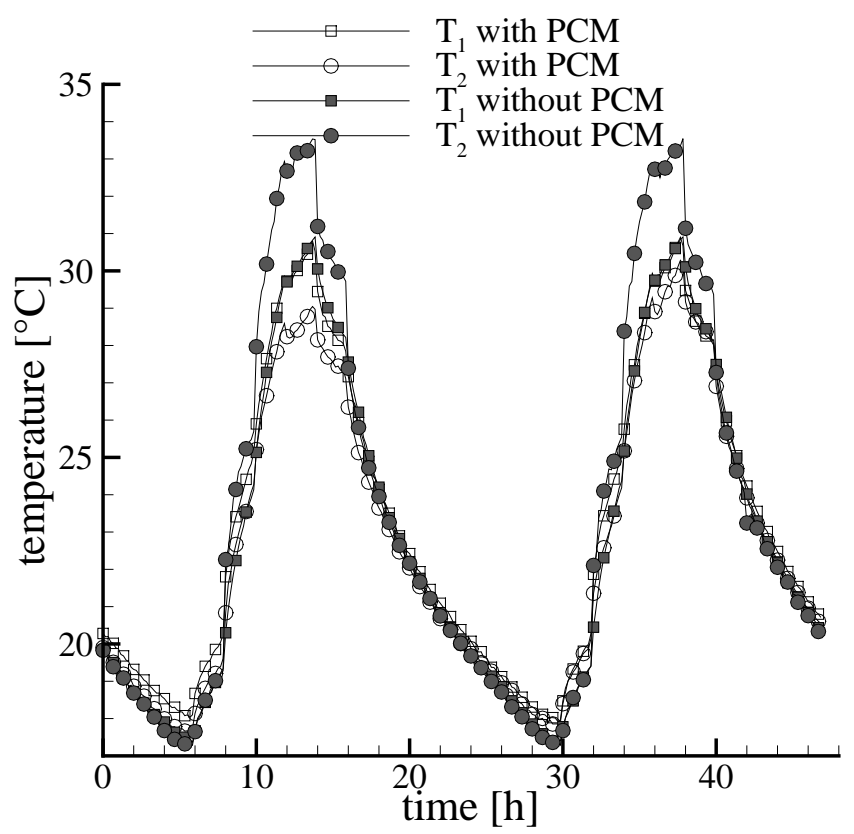

Fig. 10. Temperatures in the room for the mid-season case $-T_{1}$ at height $0.85 \mathrm{~m}$ and $T_{2}$ at height $1.70 \mathrm{~m}$. 

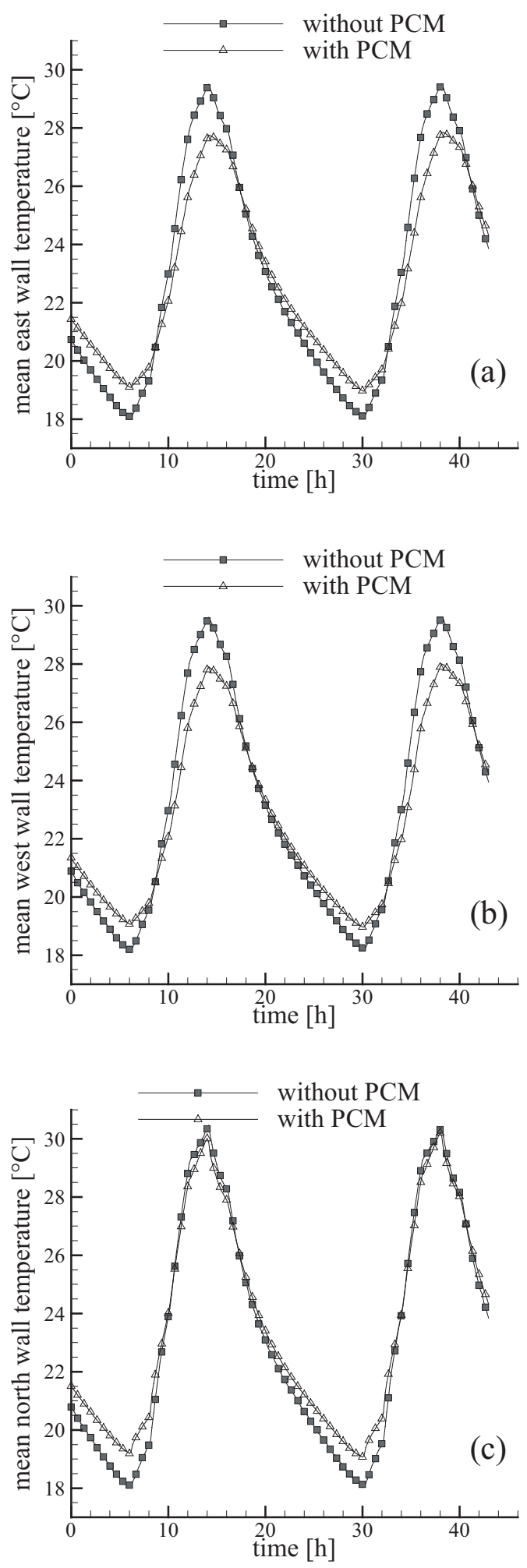

Fig. 11. Experimental mean temperatures of the interior surfaces of east wall (a), west wall (b) and north wall (c) - mid-season case. 


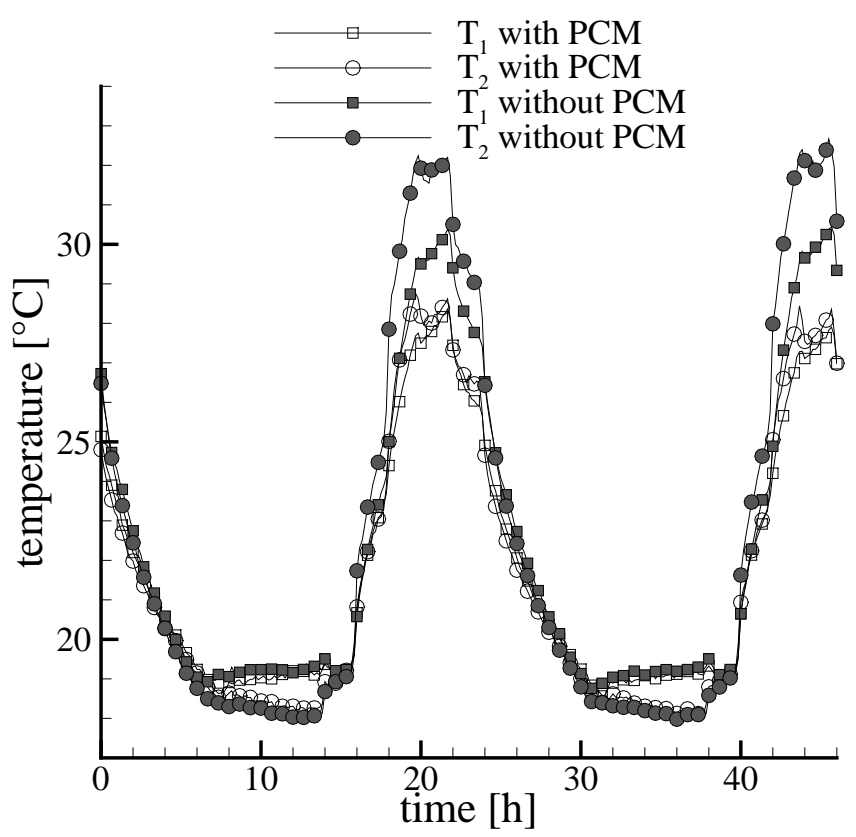

Fig. 12. Temperatures in the room for the winter case $-T_{1}$ at height $0.85 \mathrm{~m}$ and $T_{2}$ at height $1.70 \mathrm{~m}$. 

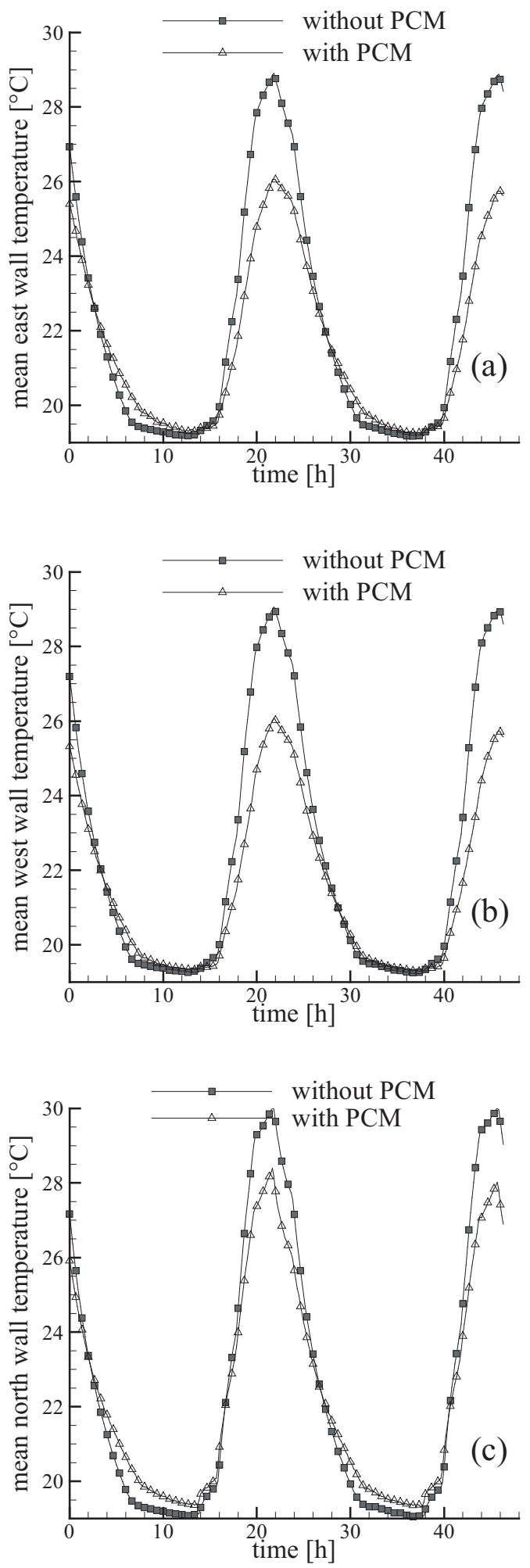

Fig. 13. Experimental mean temperatures of the interior surfaces of east wall (a), west wall (b) and north wall (c) - winter case. 